\title{
The Import Sales Contract System in Shanghai 1903-1918, with Special Reference to US-Chinese Commercial Disputes
}

\author{
Eiichi Motono* \\ Waseda University \\ ${ }^{*}$ Corresponding author. Email: byeinnyg@waseda.jp
}

(Received 11 May 2020; accepted 12 May 2020)

\begin{abstract}
This article is part of my series of articles that deal with the Western and Chinese commercial disputes from the 1880s until the outbreak of the Sino-Japanese War. In contrast to my previous articles, it deals with commercial disputes between American mercantile firms and Chinese trading merchants in the early twentieth century by examining the unpublished Shanghai American consular archives at NARA II (National Archives and Records Administration), College Park, Maryland. Together with correspondence in the North-China Herald $(\mathrm{NCH})$, these archives can be materials for revealing the peculiar behavior of the proprietors of Chinese partnership (joint-share, or hegu 合股) firms. They cooperated with American mercantile firms so long as the assets of American mercantile firms could guarantee their commercial profits. Whenever they were aware that American mercantile firms could no longer guarantee the safety of their commercial assets, they did not hesitate in breaching commercial contracts by means of various tactics. Seen from the American side, it was nothing but a betrayal. Following typical cases in the records, this article reveals the process by which these commercial disputes escalated to such a level that leaders of Chinese mercantile people demanded reforms to the commercial court system at the end of the 1910s.
\end{abstract}

Keywords: US-Chinese commercial disputes; Chinese partnership (joint-share, or hegu 合股) firm; the Mixed Court in Shanghai; suretyship; merchant of standing (timian shangren 体面商人)

From the early nineteenth century, Western mercantile firms in China, led by the British, faced the problem of how to compel Chinese trading merchants to fulfill the commercial contracts they entered into. Although this became one of the primary causes of the two Anglo-Chinese wars in the middle of the nineteenth century, we have little access to the details of the ordinary relationships between these Western mercantile firms and Chinese merchants prior to the end of the nineteenth century. Even in the case of commercial disputes, however, it was only in the 1860s, with the opening of the Mixed Court in Shanghai, and of the consular courts that enforced the law in other treaty ports, that records began to be kept that allow us to discover specific cases and the details of their disputes.

Based on the analysis of several typical cases from the middle of the 1860 s until the first half of the $1880 \mathrm{~s},{ }^{1}$ we can determine that the most common cause of Western-Chinese commercial disputes was the asymmetrical structure in fulfilling a commercial contract. In this much, when it came to British mercantile houses buying Chinese goods, because of the huge scale of capital involved, the British firms were frequently set up as if they were sureties of their compradors' private commercial contracts

\footnotetext{
${ }^{1}$ Motono 1992; Motono 1996; Motono 2000.

(c) The Author(s), 2020. Published by Cambridge University Press. This is an Open Access article, distributed under the terms of the Creative Commons Attribution-NonCommercial-ShareAlike licence (http://creativecommons.org/licenses/by-nc-sa/4.0/), which permits non-commercial re-use, distribution, and reproduction in any medium, provided the same Creative Commons licence is included and the original work is properly cited. The written permission of Cambridge University Press must be obtained for commercial re-use.
} 
with the Chinese vendors, from whom the goods were sourced on credit. In the event that the compradors then failed to fulfill their contracts with the vendors, the British mercantile houses were held responsible for their terms, and typically forced to pay the debt to the Chinese vendors in full.

By contrast, when a commercial contract between Western mercantile firms and Chinese trading merchants for selling imported Western goods was breached, it was difficult to settle the dispute in a way that was satisfactory for the Western vendors. Even when, as sometimes happened, a British creditor sued a Chinese debtor in the Mixed Court in Shanghai and was able to obtain a favorable judgment, it was often the case that the Chinese debtor absconded from the Shanghai settlement with his property intact or managed to negotiate a reduced debt.

In 1902 and 1903, the British, American, and Japanese governments forced the Qing central government to reform its judicial system so that their mercantile firms in China could settle commercial disputes with their compradors or Chinese trading merchants living outside the Shanghai foreign settlement by ratifying treaties respecting the commercial relationship. ${ }^{2}$

At the same time, the Shanghai consular body, led by the British consul-general, proposed that the diplomatic corps in Beijing revise the rules of the Mixed Court of 1869 so that every criminal and civil case between a foreign and a Chinese resident in the Shanghai International Settlement should be examined by the Chinese Mixed Court Magistrate accompanied by a foreign assessor. If the judgment was split, the case would be appealed to the Shanghai Daotai and the consul-general of the defendant nation; no warrants against a Chinese resident could be valid without the countersignature of the chief consul-general.

These proposals appalled the Chinese merchants. Their fear was that the Shanghai Municipal Police would now be able to arrest any Chinese resident with high social capital and have them immediately imprisoned once a warrant countersigned by the chief consul-general had been issued. Fearing such a revision of the Mixed Court Rules of 1869, they threatened both the Municipal Police and Western society in Shanghai by rioting on December 18, 1905. As a result, the consular body, for the time being, was forced to abandon the proposal to reform the Mixed Court system. ${ }^{3}$

Yet, the consular body did not acquiesce in its desire to reform the Mixed Court system. Taking advantage of its opportunity to take control of the Mixed Court and the assets of the Shanghai Daotai until the political turmoil of the Xinhai revolution had subsided, it implemented the systemic reforms proposed by Western assessors. First, it placed the jail of the Mixed Court under the control of the Municipal Police. Accordingly, the officers of the Municipal Police took over such tasks as investigating disputes (especially commercial disputes involving foreign residents and the delivery of warrants and orders issued by them). Next, it agreed that foreign assessors would attend the trial of civil cases - even between Chinese residents - so long as the trials took place within the International Settlement. ${ }^{4}$ In addition to these arrangements, the consular body and the Mixed Court frequently requested that the Chinese local district courts (difang shenpanting 地方審判庁) should fulfill judgments on their behalf, which meant that the Chinese local district courts would collect the accompanying debts from Chinese debtors.

To what extent, then, did the above reform and arrangement bring about a satisfactory outcome for Western creditors? How did the Chinese debtors respond to the reform, and to the way it implied that the unknown character of Chinese society was reflected in its commercial relationship with Western mercantile firms? These are the main issues I will address in this article.

To solve these questions, I will use a newly discovered series of documents detailing commercial disputes between Western mercantile firms and Chinese trading merchants in the early twentieth century. This material was discovered in the unpublished Shanghai American consular archives at NARA II (National Archives and Records Administration), College Park, Maryland (recorded as

\footnotetext{
${ }^{2}$ Article 12 of the British Treaty respecting Commercial Relations, etc. in 1902; Article 11 of the Japanese Supplementary Treaty of Commerce and Navigation in 1903; and Article 15 of the United States Treaty for the Extension of Commercial Relations in 1903.

${ }^{3}$ Motono 2012.

${ }^{4}$ Motono 2018.
} 
the US-NA Regional Group 84; hereafter, I will only quote the volume number recorded in the Group). The files of the American consulate-general in Shanghai consist of a collection of detailed commercial disputes between American firms and Chinese debtors recorded in both English and Chinese. Besides providing an outline of the commercial disputes, the Shanghai American consular archives document what took place between the proprietors of Chinese partnership firms and their relationship with their sureties, or with prominent merchant guilds in Shanghai. Such information was seldom recorded in the North-China Herald or in the Shanghai British consular archives (FO228), the main sources for commercial disputes between British and other foreign mercantile firms, including Japanese firms and Chinese trading merchants.

By following the correspondence of the US-Chinese commercial litigants recording the behavior of Chinese debtors, consumers, and their sureties, I would like to illuminate the historical character of Chinese partnership (joint-share, or hegu 合股) firms and the typical patterns of Chinese partners when sued by American mercantile firms. Through this analysis, I will also consider how Chinese people regarded and treated American and Western firms in general.

More specifically, through an analysis of the behavior of the Chinese who caused, or were involved in, these commercial disputes with the Americans, I would like to prove that risk avoidance was a more important factor than profit-making in Chinese society.

\section{Structure of the US-Chinese Commercial Disputes, 1903-1911}

After the US government signed the Treaty for the Extension of Commercial Relations in 1903, the US consulate-general began to record details of commercial disputes between American firms and Chinese partnership firms. The typical character of these disputes is recorded in the following two cases.

\section{Case 1: “Frazar \& Co. (豐泰洋行) v. Zung Feng-zai (成豐瑞)”}

In the first of these cases, the defendant Chinese firm was an imported cotton piece goods dealer established by four Chinese merchants, Ying Yung Chao [sic] (殷勇記), Woo Fong Yung, Long Mung Soon [sic] (郎孟記), and Oong Chun Chuen (翁敬傳), in March (i.e. the second moon) 1897. The firm's capital, Tls. 2,000, was divided into ten shares ( $g u$ 股): Ying took six shares, Long took two, Woo and Oong took one each, and Oong was nominated as manager. In 1898, Woo sold and transferred his one share to Long. A dispute then arose among the remaining three proprietors about dividing a profit of over Tls. 20,000. In February or early March 1899, Long Mung Soon sued Oong Chun Chuen for refusing to divide the profit. The reason for the dispute was not recorded in the sources of the case.

The Shanghai country magistrate instructed the Piece Goods Guild (Zhenhuatang yangbu gongsuo 振華堂洋布公所) to settle the case as follows: Oong should pay Long Tls. 7,500, with Tls. 600 of that in lieu of his capital investment, the balance being what was due to him as profit. Oong paid the amount to Long as instructed. According to a statement by the chairman of the Piece Goods Guild, Long Mung Soon recovered the capital he had invested in the Zung Feng-zai firm, together with the profits to which he was entitled. After this, the Zung Feng-zai firm was solely owned by Oong and he alone was responsible for all import goods already ordered, or that might be ordered in the future.

Meanwhile, Ying Oong Sze (殷翁氏), the wife of Ying Yung Chao, decided to give up her interest in the business of the Zung Feng-zai firm following her husband's death. Oong acquired Ying Yung Chao's shares, paying Tls. 1,200 to Ying Oong Sze. This meant Oong alone would be liable for the profits and losses of the business. ${ }^{5}$ As evidence of this, Ying Oong Sze and Lung Mun Soon dissolved

\footnotetext{
5"Translation of Judgment submitted by the Magistrate of the Mixed Court to the American Assessor," date unknown, vol. 887 vol. II, pp. $253-56$.
} 
their partnership in the Zung Feng-zai firm in July (i.e. the sixth lunar month) 1900, and the dissolution of their partnership was posted in the Sun [probably Shenbao 申報] and Sin [probably Xinwenbao 新聞報] papers. ${ }^{6}$

Unfortunately, news of the dissolution was not well publicized among the Western mercantile community in Shanghai. Therefore, when a dispute did arise, over breach of contracts to sell American cotton goods in 1899 and 1900, the plaintiff American firm - unaware that Ying Yung Chao had died - sued not only the Zung Feng-zai firm, but also the three proprietors: Oong Chun Chuan, Ying Yung Chao, and Long Mung Chee. Petitioning the Mixed Court in July 1903 and January 1905, the plaintiff claimed these parties were all jointly responsible for the debt on the goods they had delivered to the Zung Feng-zai firm, which was eventually valued at Shanghai Tls. 71,674.10. ${ }^{7}$

Although the Mixed Court ruled that the defendant firm and its three proprietors should pay the debt in October (i.e. the tenth moon) 1902, the defendants did not obey the judgment, owing to their partnership's earlier dissolution. Ying Oong Sze and Long Mung Soon petitioned the Shanghai Daotai to reverse the judgments, or to allocate some other form of relief. In their petition, dated October 3, 1905, Ying and Long stated that the dissolution of their partnership with the Zung Feng-zai firm sometime before July 1900 was reported to the Piece Goods Guild and advertised in the Chinese and foreign language newspapers. This meant, they contended, that the American firm Frazar \& Co. must have known of the changes and should have instituted enquiries at the time. ${ }^{8}$ However, their appeal was turned down, and Ying Oong Sze and Long refused to attend the Mixed Court again, ignoring warrants that had twice been issued. ${ }^{9}$

Frazar \& Co. rebuffed these claims. They pointed out that all the orders were contracted between 1899 and 1900, during which time all the defendants were still partners of the Zung Feng-zai firm, and they had made many attempts to settle with the Chinese firm out of court prior to the commencement of the suit. In addition, they emphasized that it could not be possible for an individual or firm to avoid contracts already entered into by dissolution because business in Shanghai and elsewhere was frequently the property of one man. ${ }^{10}$

The Mixed Court sided with the plaintiff. Having examined the relevant records of both parties, the Mixed Court again passed judgment against the partners of the Zung Feng-zai firm jointly. The primary reason given was that Oong was never sued individually, but that all proceedings were taken against the Zung Feng-zai firm, which included all the partners.

According to the judgment, the question to be decided was therefore whether, after the dissolution, the Zung Feng-zai firm had agreed to release the outgoing partners from their liability. In every civilized country, the convention held that, when a number of persons associated themselves in a partnership and that partnership entered into contracts with another firm, one or more of the partners could not subsequently divest themselves of liability by a mere notice to the other party, nor with any other man - and so nor could the three partners of the Zung Feng-zai firm. Having entered into these contracts on the understanding that the three men were jointly responsible for the contracts' fulfillment, two of those men could not then shift their liability onto the shoulders of a third without the consent of the other party to the contracts - in this case, Frazar \& Co. ${ }^{11}$

\footnotetext{
${ }^{6}$ The English translation of "Dissolution of Partnership, June 5, 1900" in vol. 887 vol. II, p. 268. Original Chinese advertisements were issued in Shenbao, June 5, 6, and 7, 1900 as “成豐瑞興記號聲明.” Since the back numbers of Xinwenbao are not available in Japan, I have not been able to locate the Chinese advertisement in that newspaper.

7"Frazar \& Co. v. Zung Feng-dai [sic]," July 28, 1903; "Frazar \& Co. v. Oong Chin Chuan, Ying Yung Chee, Long Mung Chee," January 7, 1905 in vol. 887 vol. II, pp. 224-25, 227.

8“The Humble Petition of Yin [sic] Yung Kee deceased (represented by Sun Yuen Ching his representative) and Long Mang Kee of Shanghai in the Empire of China, Merchants, 3rd October, 1905, translated by C. R. Holcombe," vol. 887 vol. II, pp. 240-43. Original Chinese texts attached to the same volume, pp. 244-46.

9"J. H. Arnold (American Assessor) to James L. Rogers (American Consul-General)," October 26, 1905, vol. 887 vol. II, pages unrecorded.

10"Frazar \& Co, vs. Zung-Foong-Sai, Re appeal," date unrecorded, vol. 887 vol. II, pages unrecorded.

11"The judgment by the Mixed Court on Frazar \& Co. vs. Zung Feng-sai with Chinese translation attached," date unknown, vol. 887 vol. II, pp. 258-67.
} 
Case 2: “The American Trading Company (茂生洋行) v. Yah Chang Tah (協昌泰), Ga Mow Shing (葛茂常), Chu Van Teh (朱文徳), and Eng Gin Fang (殷琴訪), 1905-1907”

The second case arose as the result of frustrated negotiations between two merchant firms over fulfilment of commercial contracts issued between August 24, 1903 and February 27, 1905. Once again, the issue of payment for imported cotton goods was at the heart of the dispute. The defendant firm, Yah Chang Tah, had placed a considerable order for cotton piece goods with the plaintiff, the American Trading Company. However, after arriving safely in China, the imported goods were damaged in flooding on September 1, 1905. Likely perceiving that chances of selling on the order were now slim, the defendant firm neither took delivery of the goods nor issued payment, despite pressure from the plaintiff. The American Trading Company thus decided to institute proceedings in the Mixed Court, claiming that the defendant firm and its three partners should take delivery of the ordered goods and pay the entire cost, with interest, of Tls. 92,181.69. ${ }^{12}$

Meanwhile, Ga Mow Shing, whose legal name was Keh Mow Chang, claimed that since the Yah Chang Tah firm was a partnership between him and another two Chinese merchants - Li Khay Chee (李愷記) and Li Hung Chee (李亨記) - and since that partnership had been dissolved on August 12, 1904, all liabilities of the Yah Chang Tah firm were now transferred to Chu Van Teh. As evidence for the claim, Shing submitted a Chinese document recording the dissolution, dated August 1904.

According to the document, the three former partners had no further desire to be partners in business due to a disagreement of opinions; they therefore discharged their whole capital of Tls. 3,000, together with a loss of Tls. 7,200. This implied that the responsibility to fulfill every contract signed by Yah Chang Tah was transferred to Chu Van Teh. As evidence of this, "the goods on hand and those having been ordered by different foreign firms as well as the current accounts shall be assigned to Yue Kee (裕記) and Chu Foh Kee (朱福記) for settlement." When the mutual agreement was made, the former partnership agreement, the capital book, and the seals were all cancelled, split, and destroyed in the presence of the former partners, and the total business of the Yah Chang Tah firm was transferred to the new Yue Chee firm, the owner of which was Tsze For Chee (i.e. Chu Van Teh [朱文徳]). Citing the terms of this agreement, the defendant Ga Mow Shing claimed he neither had any knowledge of the matters referred to by the plaintiff, nor any liability for the associated sum of Tls. 92,181.69. ${ }^{13}$

The key issue at contention in the case was therefore whether the date of dissolution recorded in the Chinese document was correct, and whether the three former partners were jointly liable to the plaintiff firm for all contracts stamped with the seals used under their partnership deed. This, however, was not clear cut. Although the evidence given by the defendants clearly stated the seals had been destroyed on August 12, 1904 when the dissolution agreement was made, the last contract entered into with the American Trading Company under the old seal was dated December 1, 1904. That proved the old seal, which they claimed had been destroyed on August 12, 1904, was still in use as late as December 1 in the same year. Moreover, the first contract that bore the new seal with the two characters of Yue Chee was not issued until January 25, 1905.

Based upon this evidence, the Mixed Court ruled that the former partners of the Yah Chang Tah firm were still liable to the plaintiff firm. Yet, despite this apparent victory for the American Trading Company, retrieving the debt would be another matter. Excepting Chu Van Teh, all the partners absconded, and the goods imported according to the contracts under the old seal were damaged by floods on September 1, 1905 when the goods were stored in the godowns of the public wharves. ${ }^{14}$

\footnotetext{
12“The American Trading Company against Yah Chang Tah, Ga Mow Shing, Chu Van The, Eng Gin Fang, August 16, 1905," vol. 887 vol. I, pp. 166-69; "Yah Chong Tah [sic.], date unknown," vol. 888 vol. III, p. 188.

13“The American Trading Company against Yah Chang Tah, Ga Mow Shing, Chu Van The, Eng Fin Fang," September 5, 1905, vol. 887 vol. I, pp. 169-70; "Translation of Acquittance with original Chinese text," vol. 888, vol. III, pp. 171-72; "Assignment of Shares," vol. 888, vol. III, pp. 173-74.

14“Yah Chong Tah, May 17, 1906," vol. 888 vol. III, pp. 188-89.
} 
The reason that Kuh Mow Che and other partners were able to abscond was that the Chinese runners of the Mixed Court leaked the information of their arrest after taking a large bribe. ${ }^{15}$ As a result, the plaintiff firm was only able to collect Tls. 6,000 out of the total liability of Tls. 92,181.69. ${ }^{16}$

Looking at the outline of the above two cases, it is apparent that both sets of Chinese defendants used similar tactics to avoid their liability, and these cases were by no means exceptional. Two anonymous correspondences sent to the editors of the North-China Herald, in fact, suggest the Chinese debtors were operating in the context of what was becoming an evasive business culture. The first correspondence, sent by "Merchant," outlines the Chinese trading merchants' modus operandi as follows:

The majority of dealers, after fixing up the prices, time of delivery and time of clearance of a cargo, close a deal with foreign firms, this virtually becomes a contract, and is governed under the law of contracts. But they do not keep a contract lately, and they make endless excuses, trying to get out of it. Their excuses run up to this, in a few words: "exchange bad," "market bad," "money very tight"; but all these do not hold water with the Banks or foreign merchants abroad. A contract is a contract and must be kept as the foreign firms out here in turn have their contracts to fulfil with merchants abroad and the local Banks. Any turn of this kind makes their position awkward.

If one studies every case closely, you will find that the Chinese are very shrewd, and one will ultimately come to the conclusion that the Chinese who have failed to take up contracts, have one and all over-speculated with foreign money and cargo - heads he wins, tails I lose policy. ${ }^{17}$

Why did the Chinese trading merchants suddenly exhibit such strange behavior so that they could avoid their liability? "An open letter by a leading Chinese merchant," published in the North-China Herald two months before the correspondence from "Merchant," revealed the historical background.

The primary reason for the increase in the Western-Chinese trade was the decrease in the distribution trade of Shanghai since 1900, when Western firms opened branches in Tianjin and Niuzhuang. This tendency was accelerated by the end of the Russo-Japanese War. In contrast to the expectation of Western firms, the demand for imported cotton goods declined and the market fell into a slump from 1906. Consequently, the import trade in colored cotton piece goods was almost ruined, and those who engaged in the business suffered great losses. Nevertheless, many Western firms, which by and large were ignorant of the situation, continued to direct their shroffs to go about and recklessly invite people to make contracts for cotton piece goods. Since the shroffs' principal motivation was to increase the number of commercial contracts for their employers, they had little concern that such contracts might never be fulfilled. In the case of imported colored cotton piece goods, the situation yielded a surplus stock large enough to meet demand for three years. Compounding this poor position in 1907 were a financial crisis, a bad harvest, and floods, which collectively caused the exchange rate of pound sterling to silver tael to fall to "such an unprecedented extent that [cotton] piece goods men one and all suffered great losses therefrom." According to "a leading Chinese merchant," no day passed without a report of Western mercantile firms bringing suits against Chinese firms for failing to take delivery of goods. As a result, some proprietors of Chinese partnership firms were forced to close their businesses. No sooner were the summonses issued by the Mixed Court than the confusion began. Those who had advance information from the Mixed Court runners that Western creditors would take legal steps to sue them absconded. ${ }^{18}$

Western merchants, of course, would not accept such behavior from their Chinese debtors. This was confirmed by "Merchant" in his correspondence to the editor of The North-China Herald, who emphasized:

\footnotetext{
15“H. B. Kayfan to James L. Rodgers, May 17, 1906," vol. 888 vol. III, p. 189.

16“Yah Chong Tah, May 17, 1906," vol. 888 vol. III, p. 189.

17“The Mixed Court Hearing List: Merchant," NCH, August 8, 1908, p. 352.

18“The Piece Goods Trade: An Open Letter by a Leading Chinese Merchant," NCH June 13, 1908, pp. 688-89; Motono 2015, pp. 378-79.
} 
A contract is a contract and must be kept as the foreign firms out here in turn have their contracts to fulfill with merchants abroad and the local banks. Any turn of this kind makes their position awkward. $^{19}$

\section{Escalation, 1908-1911}

Despite their apparent success in the Mixed Court, those American firms that sued Chinese debtors and obtained judgments in their favor rarely, in fact, managed to collect the debt. The records of the following five civil cases reveal the Mixed Court system, in effect, as toothless. According to Hamilton Butler, the American assessor of the Mixed Court, judgments in three out of five cases were not enforced, and the remaining two were not even placed on the hearing list. The most common reason why this should be was made explicit in the case documents.

First of all, if a Chinese defendant was a man of good connections with powerful local bureaucrats, he was quite capable of treating the judgment as null due to the latitude afforded by his political influence. ${ }^{20}$ Alternatively, when a defendant was a man of good family, he could reject the judgment simply by boasting that he was immune from the orders of the Mixed Court, even if he could afford to pay the amount required by the judgment. In such cases, the reason for immunity was recorded as "an open question". ${ }^{21}$ Therefore, when defendants had a politically influential person as their guarantor, the Mixed Court magistrate might neither issue a warrant for their arrest nor attempt to enforce the judgment in the case. ${ }^{22}$ Yet, these were not the only ways to avoid payment. Even when the defendant was neither a man of good family nor one with an influential guarantor, he could still evade being forced to pay the amount required by the judgment by bribing the Shanghai county yamen runners. ${ }^{23}$

In these situations, however strongly the American assessor urged the favorable settlement of cases for the American plaintiffs, the Mixed Court magistrate could do nothing for them. ${ }^{24}$ By way of response, American firms stiffened their resolve, and from 1909 onwards their attempts became merciless.

The following five cases were typical of this process. In the first two, the plaintiff, once again, was the American Trading Company (茂生洋行), which refused to loosen its grip until it had collected the liabilities in full from its Chinese debtors. In the first case against Chien Kun Yuen and Shen Chu Chien, the proprietors of a Chinese partnership firm, Chih Hsing Ch'ang, the Mixed Court sentenced the defendants to pay a debt of Tls. 2,050 within two weeks, having breached an import trade contract. The plaintiff, meanwhile, was ordered to return the imported goods, which it had confiscated. ${ }^{25}$

In the face of the judgment, Chien proposed to Sheng Chih Chien that they share the debt together. However, Sheng turned the proposal down, claiming that he was not a partner of the Chinese firm, Chih Hsing Ch'ang. Accordingly, the two men were imprisoned in the Mixed Court jail without further trial, while the plaintiff firm sold the confiscated import goods to their comprador - an arrangement that clearly breached the judgment. Hearing that the plaintiff firm had sold the imported goods they were due, but was nevertheless requesting payment of the deficit of Tls. 800, the two imprisoned defendants and their surety, Sheng Yu-sheng, requested that the plaintiff firm should submit an accurate list of the sales and that the Mixed Court should release them. ${ }^{26}$ From then on, no further record of the case exists, and it is uncertain whether the plaintiffs succeeded in collecting the debt.

\footnotetext{
19“The Mixed Court Hearing List: Merchant,” NCH, August 8, 1908, p. 352.

20"Memorandum, Singer Sewing Machine Co. vs. Dai Yu King, date unknown, 1908," vol. 886, p. 47.

21 "Singer Sewing Machine Co. vs. Ban Kan Ching," vol. 886, p. 48.

22"J. M. Pa Vitt vs. Zee King Foo et Zee Young Foo," vol. 886, p. 48. One of the guarantors of the defendants in the case was Chu Pao San (朱葆三), who was a director of the Shanghai General Chamber of Commerce.

23"Markt and Company vs. Hsing Yuen, date unknown, 1908," vol. 886, p. 53.

24"M.C. No. 277, Hamilton Butler to Charles Denby, December 29, 1908," vol. 886, p. 55.

25“Judgment, January 15, 1910," vol. 901, p. 21.

${ }^{26}$ "No. 466 American Trading Co. vs. Chien Kun Yuen et al., August 22 and 24, 1910," vol. 901, p. 212; "Copy of petition from the defendant in the case of the American Trading Co. vs. Chien Kun Yuen et al., August 22 and 24, 1910," vol. 901, p. 213; "No. 691 Substance of petition of Chien Kuo Cheng, defendant in the case of American Trading Co. vs. Sheng Chih
} 
The second case was brought about by the financial crisis of 1910. The defendant in the case, Chao Kuang Ching, was a proprietor of a Chinese partnership firm, Ching Foong. Besides the American Trading Co., a British and a German firm also failed to collect a huge sales debt from the Ching Foong firm. Although the creditors succeeded in confiscating the assets of Chao Kuang Ching and dividing them according to the amount of their credit, the American Trading Co. still suspected that Chao Kuang Ching was hiding funds that could be used to pay the balance. They requested that the Mixed Court imprison him until the pro rata division of Ching's concealed wealth was completed so that they could collect their entire debt. ${ }^{27}$

For the Chinese merchant community, this was a worrying turn of events and the plaintiff's request was greeted with fierce opposition. Once news of Chao Kuang Ching's imprisonment spread, more than fifty-one Chinese cotton import dealers petitioned the Shanghai Daotai for his immediate release, claiming that, since Chao Kuang Ching had lost his assets in full, he could not pay back the balance of his debt. ${ }^{28}$

The Shanghai Daotai, Liu Yanyi (劉燕翼), under heavy pressure from the Chinese merchants, ordered the Mixed Court Magistrate, Bao Yi (寶頣), to negotiate with the American assessor and the Shanghai county magistrate, Tian Baorong (田寶榮). As a result, Chao Kuang Ching's remaining debt was reduced from Tls. 1,175 to Tls. 1,000, and Chao Kuang Ching was ordered to sell the contracted goods within three months with his newly appointed surety. ${ }^{29}$

Even this strong stance from the Mixed Court magistrate against Chinese debtors did not always lead to a satisfactory outcome for the American firms, however. It was not unusual, for example, for Chinese debtors to flee the Shanghai International Settlement, so as to avoid arrest and being returned to the Mixed Court. In such cases, the typical shape of subsequent events was recorded in the case "The Yek Tong Lin Fire and Marine Insurance Company vs. Chu Shih Shen." The defendant in this case was a guarantor, who had facilitated the mortgage between the plaintiff firm and Liang Ki Tze, the bona fide defendant. Since Liang had failed to pay back the debt, the plaintiff sued Chu Shih Shen in the Mixed Court. Chu was then imprisoned in the Mixed Court jail for more than a year before being released on bail on the condition that he should pay his liability within three months. ${ }^{30}$

Nevertheless, after three months had passed, Chu Shih Shen still had not settled the case. When the plaintiff company requested that $\mathrm{Chu}$ be returned to the Mixed Court to pay the debt, $\mathrm{Chu}$ replied that he was under no obligation to guarantee payment with his own assets, claiming his guarantee note only obligated him to settle with the plaintiff. ${ }^{31}$ Even the Mixed Court magistrate replied to the American assessor that it would be impossible to carry out the request, as Chu Shih Shen had been expelled from the Settlement and the Municipal Police were unable to locate him. ${ }^{32}$

Nearly two months later, Chu Shih Shen was found in Suzhou, looking for a job. He refused to appear in the Mixed Court, claiming that he only had a responsibility to settle the case with the plaintiffs but had no obligation to repay the plaintiff's claim from his assets. ${ }^{33}$ In October 1910 he

Chien et al., October 16 and 17, 1911," vol. 902; "No. 740 American Trading Co. vs. Chih Hsing Ch'ang, January 18 and 19, 1912," vol. 767.

${ }^{27}$ No. 362 “The American Trading Co. vs. Ching Foong, March 24 and 29, 1910," vol. 901, p. 88; No. 381 “The American Trading Co. vs. Ching Foong, April 13 and 14, 1910," ibid. p. 107; No. 499 “The American Trading Co. vs. Ching Foong, November 3 and 4, 1910," ibid., pp. 288-89; No. 441 "The American Trading Co. vs. Ching Foong, August 10 and 11, 1910," ibid. p. 207; No. 692 “The American Trading Co. vs. Ching Foong, October 17 and 19, 1911,” vol. 902.

${ }^{28}$ Nos. 560, 598, 606a, 622, 693 "The American Trading Co. vs. Chow Kuan Ching, February 21, April 20 and 21, May 2 and 3, June 3 and 5, October 20 and 21, 1911," vol. 902.

${ }^{29}$ Nos. missing, 628, “The American Trading Co. vs. Chow Kuan Ching, June 9, 10, 12, 1911,” vol. 902.

${ }^{30}$ No. 399 "Copy of Petition from Chu Shih Shen, the defendant in the case of the Yek Tong Lin Fire and Marine Insurance Company vs. Chu Shih Shen for not redeeming the mortgage, May 2, 1910," vol. 901, pp. 141-42.

${ }^{31}$ No. 394 “The Yek Tong Lin Fire \& Marine Insurance Co. vs. Chu Sih Seng, May 5, 1910,” vol. 901, p. 123. His claim was based upon a peculiar characteristic of the Chinese surety system. See Niida Noboru 1962, pp. 554-59.

${ }^{32}$ No. 447 "Yek Tong Lin Fire and Marine Insurance Co. vs. Chu Sih Seng, August 23, 1910," vol. 901, p. 214.

${ }^{33}$ No. 466 "Yek Tong Lin Fire and Marine Insurance Co. vs. Chu Sih Seng, September 23, 1910,” vol. 901, p. 241. 
absconded again from Suzhou. Although the next month the Municipal Police located him in Shanghai, the following month $\mathrm{Chu}$ Shih Shen fled again, and this time he went missing for good. ${ }^{34}$

As this case suggests, even when the surety of the debtor was imprisoned, American firms were still not always able to collect their frozen debts, due to the endogenous obligation of a surety in Chinese society. ${ }^{35}$ Therefore, it was quite natural that American firms should make every attempt to collect their debt from someone else. A typical case was "Frazar \& Co. vs. Yen Yue," which came to court in June 1910. The defendant Chinese partnership firm was established in 1907 as a cotton piece goods import firm by two Chinese merchants, Ching Li Yuen and Shuh Pu Kee, within the International Settlement. After the death of Ching Li Yuen, the total assets of the Yen Yue firm were inherited by Shuh $\mathrm{Pu}$ Kee in 1908. When Shuh Pu Kee failed to redeem the debt, at the request of Frazar \& Co. the Mixed Court ordered the arrest of Shuh Pu Kee’s surety, Li Pah Pao (李伯葆). This must have caused a sensation among the Chinese since Li Pah Pao was the chairman of the Tseng Hua Tang Foreign Piece Goods Guild and a typical "merchant of standing (timian shangren 体面商人)." 36

That case was merely the tip of the iceberg, however, and the US Singer Sewing Machine Co. (勝家縫衣機器公司) was involved in a more relentless series of attempts at debt recovery. In the early twentieth century, Singer sold their products to Chinese customers in installments without any due diligence to ascertain whether customers could afford to pay the total cost of the sewing machine. As a result, many Chinese customers failed to fulfill the installment schedules and thus became subject to commercial litigation. In Tianjin, 1,651 debtors neither paid the total price of the sewing machines nor gave them back to the company. Since it was impossible for the company to sue these debtors in the consular court, Singer Sewing Machine Co. asked the Tianjin General Chamber of Commerce to collect the debt on their behalf, and they, in turn, cooperating with the Tianjin Daotai, called for the debtors to fulfill their contracts. ${ }^{37}$ Meanwhile, in Shanghai and its neighboring districts from July 1914 to May 1917, the names of Chinese customers and their guarantors - alongside their addresses, the value of unpaid loans, and the conditions of sales contracts - were all recorded in the form of a "conditional lease note" collected in the US consulate-general records. (See Table 1 for a listing of the information for each case).

As the frequency and the fervor of American firms attempts to collect unpaid commercial debt from Chinese customers increased in this period, the chances that their guarantors' prestige might be damaged by being imprisoned or having their assets confiscated rose. Therefore, the Chinese side also developed various strategies for evading or resisting their responsibility.

\section{The Chinese Response, 1912-1918}

Besides ordinary commercial cases, which fully recorded the activities of Chinese debtors and their guarantors, the proprietors of Chinese partnership firms rarely paid off their debts to American firms. A typical example of evading a contract obligation with an American is recorded in the case of “the Shanghai Building Company (匯芳公司) v. Jia Asi (賈阿四).” In this case, the defendant persistently avoided taking responsibility for paying his debt by nominating one guarantor after another on his behalf.

Initially, the plaintiff company had filed a claim against the defendant amounting to $\$ 136.72$ for rickshaw hire in Shanghai No. 2 Lower Shen Panting (上海第二初級審判㯖) on September 22, 1913. Although the court judge had ordered the defendant to pay the total debt, the defendant absconded immediately after being released from jail and found a guarantor to pay the debt. The plaintiff company did not receive the money from the guarantor, even though the Magistrate of

\footnotetext{
${ }^{34}$ Nos. 479, 504, 518, 545, 546, 571, 572, 582 "Yek Tong Lin Fire and Marine Insurance Co. vs. Chu Sih Seng, October 18, November 10 and 29, 1910, January 3 and 6, March 4 and 17, 1911,” vols. 901, 902.

${ }^{35}$ No. 417 "Frazar \& Co. vs. Yen Yue, June 6, 1910," vol. 901, pp. 172-74.

${ }^{36}$ No. 417 "Frazar \& Co. vs. Yen Yue, June 6, 1910," vol. 901, pp. 172-74.

${ }^{37}$ Tianjin Shanghui Dang'an Huibian （天津商會檔案匯編）(1903-1911) (天津人民出版社, 1989), pp. 1802-4. No record of the result of the notice is available in the collection of Tianjin General Chambers of Commerce archives.
} 
Table 1. Listing of information recorded in each case

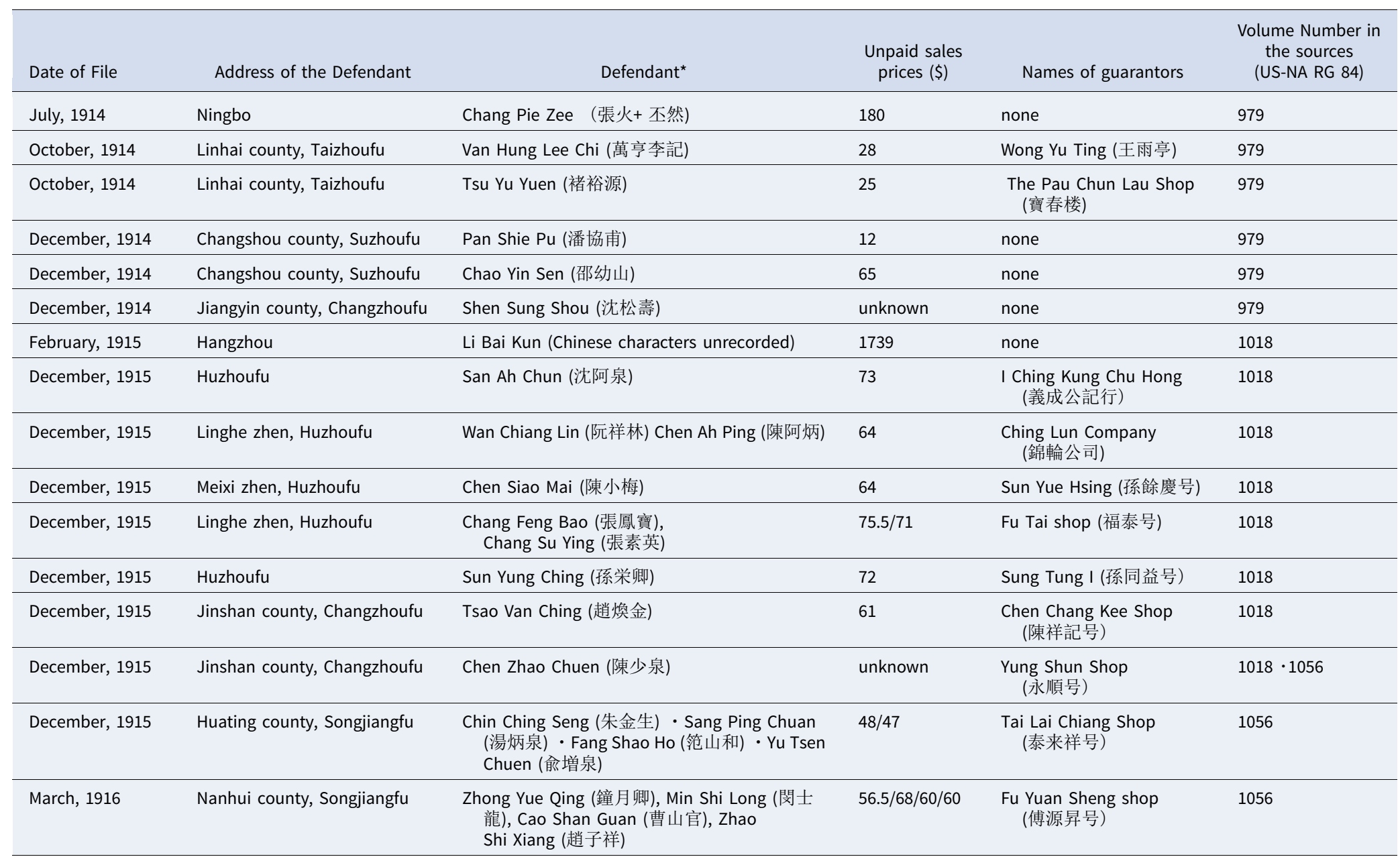




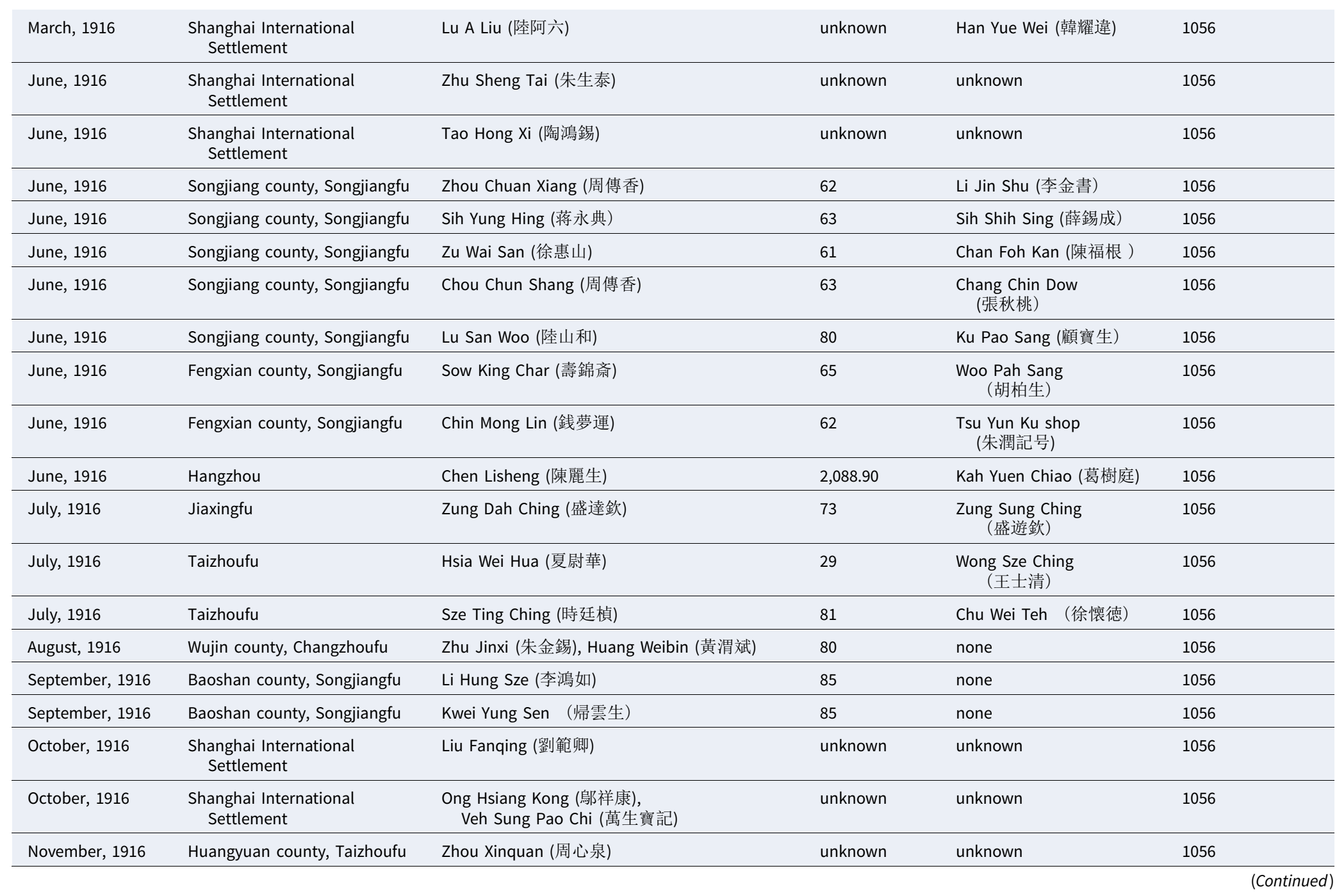


Table 1. (Continued.)

\begin{tabular}{|c|c|c|c|c|c|}
\hline Date of File & Address of the Defendant & Defendant ${ }^{\star}$ & $\begin{array}{l}\text { Unpaid sales } \\
\text { prices (\$) }\end{array}$ & Names of guarantors & $\begin{array}{l}\text { Volume Number in } \\
\text { the sources } \\
\text { (US-NA RG 84) }\end{array}$ \\
\hline November, 1916 & Gaoyou zhou, Yangzhoufu & Xia Weihua (夏蔚華), Shi Tingzhen (時廷楨) & unknown & unknown & 1056 \\
\hline November, 1916 & Changshou county, Suzhoufu & Wang Zhishan (王芝山) & unknown & unknown & 1056 \\
\hline November, 1916 & Shanghai county, Songjiangfu & Xu Shide (許世徳) & 90 & Ma Dexing （馬徳興） & 1056 \\
\hline December, 1916 & Fengxian county, Songjiangfu & Wan Gensheng (萬根生) & 76 & none & 1056 \\
\hline December, 1916 & Anji county, Huzhoufu & Chen Linchu (陳林初) & 59 & Zhou Kuhe （周克和） & 1056 \\
\hline December, 1916 & Anji county, Huzhoufu & Cai Zhenbing (蔡震炳) & 70 & Pan Mingjing （潘明鏡） & 1056 \\
\hline January, 1917 & Shangyu county, Shaoxingfu & Chen Xu Si (陳徐氏) & 87 & Xu Yichen （徐逸臣） & 1056 \\
\hline January, 1917 & Shangyu county, Shaoxingfu & Tong Youchuan (童幼川) & 90 & Wang Geqian （王鶴謙） & 1056 \\
\hline May, 1917 & Wuxi county, Changzhoufu & Zhang Zhenya (張振亜) & $1,913.07$ & $\begin{array}{c}\text { Han Zhongxian (韓仲賢), } \\
\text { Gu Yigui (顧把桂) }\end{array}$ & 1056 \\
\hline
\end{tabular}


No. 2 Lower Shen Panting had informed the plaintiff several times that he was going to send for the guarantor. $^{38}$

When the guarantor, Zhu Shunxiang (朱順祥), was finally brought before the court and ordered to pay the amount accorded in the judgment, he was released on condition that another guarantor would pay the debt on his behalf. Just as with Zhu Shunxiang, however, the new guarantors, Zhu Kongyang (朱孔陽) and Hu Yunsheng (胡雲生) of Wan Xing Soy store (萬金醬園), failed to pay up, even after having been ordered to do so several times. ${ }^{39}$ The defendants, however, eventually employed a more cunning strategy for evading the debt: they secretly replaced the official case document for a counterfeit obscuring the defendant's identity. As a result, the Commissioner of Foreign Affairs, Yang Tcheng (楊晟), believed that the defendant of the case was not Jia Asi but a certain privileged Chinese man with close connections to rich entrepreneurs and local bureaucrats. Through this gambit, Jiang Asi and his guarantors were, in the end, able to evade responsibility for paying the debt ordered by Shanghai No. 2 Lower Shen Panting.

Likewise, ordinary debtors - those without close relationships to politically influential persons, or to local bureaucrats - also frequently attempted to resist orders from the Mixed Court and the Chinese local district courts. With no other methods to rely on, such debtors rarely hesitated to resort to violence. Two relevant examples are available in records of the activities of the Singer Sewing Machine Co. in attempting to collect unpaid debts from customers and their sureties in the Shanghai districts.

The first example concerns an attempt to collect unpaid sales installments from Kiang Pek Kang (姜柏康), Qiu Ren Medicine Shop (求仁藥店), and Wah Sze Tong (屈史堂) in 1916. This case followed an effort by Ma Yukang (馬裕康), a salesman of the company, and Mo Tungsheng (莫同生), a sub-manager, to collect the remaining debt on a sewing machine from the lessee, Chu Sze-tang (Wah Sze Tong), and his guarantor Kiang on June 8, 1916. The debt collectors were not only refused payment but also attacked, ill-treated, and handed to the local police before being transferred to Songjiang. In the melee, Mo Tungsheng lost his watch valued at $\$ 13.20$, and $M a$ Yukang lost a $\$ 10$ receipt book and cash amounting to $\$ 7.84 .^{40}$

However, things were not perhaps as straightforward as this suggests. In a report recorded in the case documents, a local police officer's testimony provides a vivid insight into an apparently more complex situation, and this is worth quoting in full:

At 10 o'clock in the forenoon of the 8th instant Mah Yu Kong [Ma Yukang] and Mon Tung-seng [Mo Tungsheng], shroffs of the Changyen branch of the Singer Sewing Machine Company, came to the town and tried to settle with Kiang Pek-kang [Kiang Pek Kang], an employee of the Chiu Jen Drug Store [Qiu Ren Medicine Shop], the machine account of Chu Sze-tang [Wah Sze Tong], who was guaranteed by him. Claiming that the rental due by the lessee, Chu Sze-tang, had been paid to the Singer Sewing Machine Company and that the machine was returned [to] them in the morning, Kiang Pek-kong [sic] refused to make any payment on behalf of Chu Sze-tang. A hot discussion then ensued between the parties. The shroffs in question persistently urged for payment, used strong and provoking language and struck tables while speaking in the Chiu Jen drug shop. The crowd of villagers who came to the market at that time were all indignant on hearing of the nature of the trouble. So angrily and loudly did they talk that a serious agitation was very likely to take place. As we failed to disperse the crowd by suasion and as the police force was so small that we could hardly manage to suppress the trouble, it was necessary for us to detain the said shroffs for the time being and scatter the multitude so as to avoid a disturbance of great character. As my idea was to settle the difficulties in order to preserve public order, I was of the opinion that to take these shroffs to the station was to protect them from the danger of

\footnotetext{
38“Alex. N. Brlway [sic], the China Vehicle Co. to N. T. Johnson, Deputy Consul and Mixed Court Assessor, January 14, 1914," vol. 979.

39"Yang Ch'eng, Shanghai Commissioner for Foreign Affairs to American Consul-General, February 4, 1914," vol. 979.

40“Thomas Sammons to the Magistrate of Sung Kian, June 12, 1916," vol. 1056.
} 
being attacked by the crowd of villagers. The shroff Moh Tung Seng was, however, ignorant of the motives from which these measures were adopted and [was] disposed to make trouble against the police station. Without being noticed by anyone, he threw around his own neck the iron chain which was suspended on the wall in the station. This was done for the purpose of enabling himself to falsely accuse us of having ill-treated him.... ${ }^{41}$

Why did $M a$ and Mo take such a violent attitude towards Jiang and Wah? In replying to the enquiries, Jiang made the following statement:

Some time ago Chu Sze Tang purchased a sewing machine for $\$ 75$ from the Singer Sewing Machine Company. He was guaranteed by me. Apart from the payment that has already been made, he is now indebted to the Company to the extent of $\$ 38$. Owing to the fact that the Company has strongly pressed me for payment, I produced the man Chu Sze Tang and returned the machine to the Company on the 8th instant. Nevertheless, the shroffs Mah Yu Kong and Moh Tung Seng again called at my shop on that day to demand payment. They struck the tables and caused so much trouble in the premises that the crowd of spectators outside were all indignant against them. The police dissuaded Mah Yu Kong and his companion from making any disturbance but they would not agree to their suggestion with the result that they were arrested to the station. The sum of $\$ 38$ now due on the machine I am willing to pay in full to the Court. What I have said is all true. ${ }^{42}$

The Singer Sewing Machine Company made similar attempts to collect the sales prices of their sewing machines from various other debtors. ${ }^{43}$ Faced with such intimidating tactics to collect a debt or the prospect of being sued by American firms, those with most to lose were the so-called "merchants of standing (timian shangren)" who had signed a sales contract as a guarantor. Whenever a commercial contract was defaulted on, they were immediately at risk of being arrested and put into the Mixed Court jail, and with a prospective wait of between nine and ten months before trial. The despondency cause by that experience is conveyed well in a petition from a jailed guarantor:

We are all in custody at present. Some of us are wrongfully implicated, some are unable to give security while others who are able to pay their indebtedness are anxious to bring the truth to light. Except those who have really no means to meet their liabilities, none of us would consider the jail as a paradise and prefer to remain in a miserable and friendless state. There are also some persons who are unable to recover the monies due them, while they are imprisoned with the result that their reputation is seriously affected and their career ruined. Some of these persons have caused their parents [to become] sick on account of constant worry while others their wives and children [so] destitute that they have to depend upon other persons. The hardships are beyond description and those who are now undergoing such a state can do nothing besides lamenting over their fate. We are therefore compelled to have this petition written on our behalf setting forth our difficulties and requesting you to lessen the amounts required as securities, to cause our cases to be set for early hearing and to grant such and further relief as you may deem fit. ... ${ }^{44}$

\footnotetext{
${ }^{41}$ The testimony was written by the police officer, Chang Tsung Wei, and was quoted in "A letter from Li Eng Lu [李恩露], Magistrate of Sungkiang, to American Consul-General, Shanghai, June 17, 1916,” vol. 1056.

${ }^{42}$ The statement was also recorded in the above letter.

${ }^{43}$ The only other case whose process led to the enmity against the Chinese customers was recorded in "Singer Sewing Machine Company vs. Chow Liang-tung [周良棟].” The record of the case is “Copy of a dispatch from the Kiangse Foreign Office, date unknown, 1916," vol. 1056.

44"A petition from the merchants who are in custody of the international Mixed Court, October 1916," vol. 1111, original Chinese text attached in the volume.
} 
In light of such realities, the Shanghai General Chamber of Commerce petitioned the British and American assessors to reform the Mixed Court system, so Chinese guarantors could avoid being put into the Mixed Court prison. Their petition revealed how Chinese merchants perceived the "efficient" functioning of the Mixed Court in dealing with commercial disputes between Western and Chinese merchants.

When Western merchants sued Chinese merchants and their guarantors, informing the Court that the defendants were planning to escape at once, the Mixed Court requested that the Municipal Court tissue a warrant bearing the Chinese characters “Chuandao jiaobao 傳到交保.” This meant that the defendants were to be summoned and required to produce security. Consequently, the recipient of such a writ was arrested immediately, despite his respectability or status as a merchant, put into the Municipal Police's custody, and conveyed to the Mixed Court the following day, handcuffed as though he were a criminal.

The Shanghai General Chamber of Commerce accused the Mixed Court of perpetrating such treatment against Chinese guarantors on the grounds that it might result in the loss of guarantors' credit. In some cases, the level of indebtedness was so great that the sudden failure of an individual Chinese merchant could seriously affect the business community as a whole.

To protect merchants of good reputation, the Shanghai General Chamber of Commerce emphasized that it would henceforth be unnecessary to issue such warrants printed with "Chuandao jiaobao" on the summons. They also requested that the Mixed Court renew the rule "to protect the interests of individual merchants and thus promote trade conditions in general." ${ }^{\prime 5}$

The petition was nothing short of an expression of surrender by the Chinese merchants. After the end of World War I, the controversy between the Western and Chinese merchants would enter a new stage.

\section{Conclusion}

The commercial disputes between American vendors and Chinese debtors or their sureties recorded in the US consulate-general records from 1903 to 1918 reflected the process by which the cohesion of Chinese personal networks or the solidarity of Chinese commercial groups began to disintegrate and eventually disappeared. As many works have pointed out, since these personal networks or commercial groups monopolizing certain economic activities (for instance, the tea and silk export trade, or the foreign cotton goods and Indian opium import trade) appeared in the late Ming dynasty period, they had been effective in mobilizing people for certain political movements or causes in critical situations between the late Qing and early Republican periods. ${ }^{46}$

Unfortunately, the authors of these works were only interested in how such personal networks or certain groups were formulated and how they functioned within concrete solidarity. Due to the lack of relevant sources, few studies have considered the conditions under which personal ties in such networks or commercial groups with concrete solidarity gradually loosened and eventually disintegrated.

The common object of such peculiarly Chinese characteristic networks or commercial groups was to guarantee the life and property of their members. Whenever a member became aware that the common objects were lost, or that being the member of such networks or groups might come with risks, they immediately rid themselves of these personal connections and groups. This was the main reason why the prominent merchants' guilds, which monopolized the trade of popular export or import goods in certain regions, could no longer maintain their solidarity of membership as soon as they became aware that the economic activities they monopolized had ceased to guarantee their commercial interest.

Seen from this perspective, the commercial disputes dealt with in this article and the relevant correspondence in the North-China Herald can be regarded as recording and describing the moment

\footnotetext{
45“Copy of a letter from the Chamber of Commerce, Shanghai, China," attached to "A letter from Kuan Chun, Magistrate of the Mixed Court, to American Assessor, February 7, 1917," vol. 1111.

${ }^{46}$ Dillon and Oi 2008; Golas 1977; Rowe 1984; Yang 1994; Goodman 1995; Motono 2000.
} 
when the solid Chinese personal networks or commercial groups - which utilized their commercial activities with American firms as shields to protect their life and property - began to loosen and disintegrate. Without realizing it, the American mercantile firms and assessors of the Shanghai Mixed Court unconsciously recorded the behavior of the Chinese mercantile population as they became aware that their personal commercial contracts with American mercantile firms were harmful rather than beneficial.

The historical background to the series of commercial disputes discussed in this article was formed by the political turmoil surrounding the Boxer Uprising, the Russo-Japanese War, and the flood and economic crises of 1907, all of which led to a further series of financial crises from 1910 in China. ${ }^{47}$ The cumulative impact on the import goods market was to make transactions by credit or installments difficult. The consumers who bought expensive sewing machines by installment with sureties, and likewise the proprietors of Chinese partnership firms who cooperated with American firms to sell imported goods by sales in credit, became aware that commercial relations with American firms were harmful. Therefore, they took every effort to abandon those relationships.

The peculiar behavior pattern of the Chinese mercantile population dealt with in this article reveals why the mutual cooperation between Western firms and Chinese merchants broke down. Seen from the Chinese side, the relationship with Westerners in China was, after all, a device to guarantee their economic profit, their individual property, and even their lives. If they were aware that Westerners in China could no longer protect these vital elements, they would flee from their Western partners, abandoning their contracts with them.

Of course, Western firms in China were never likely to permit such selfish and lawless strategies. As revealed in this article, the American firms made every effort to force the parties to their commercial contracts - or, for that matter, their sureties - to pay the whole debt through litigation in the Shanghai Mixed Court. Although this litigation always resulted in the victory of the plaintiff, the judgments were seldom enforced to their satisfaction. This meant that the Mixed Court system under the control of the consul-generals after 1911, with the cooperation of the Chinese local district courts, could not settle commercial disputes satisfactorily for Westerners.

Meanwhile, since Chinese debtors frequently succeeded in absconding without paying the debt due mainly to the limited jurisdictions of the Mixed Court in Shanghai and the Chinese local courts it was the so-called "merchants of standing" who were forced to pay the debts on behalf of the debtors. These merchants were ill-treated by the Shanghai Municipal Police and the Mixed Court, and their dignity in Chinese society was seriously damaged. Therefore, they also needed the way in which commercial disputes with Western firms were settled to be reformed.

Thus, for both Western mercantile firms and leaders of Chinese local society, the asymmetrical structure in fulfilling commercial contracts they entered into required substantial reform. How this problem was dealt with by both sides in the 1920s is my next topic.

\section{References}

Primary sources

US-NARG84 (National Archives and Records Administration) II, College Park, Maryland NCH (The North-China Herald)

\section{Secondary sources}

Dillon Nara and Jean C. Oi (eds.) (2008). At the Crossroads of Empires. Stanford, CA: Stanford University Press.

Golas Peter J. (1977). "Early Ch'ing Guilds." In The City in Late Imperial China, ed. G. William Skinner. Stanford, CA: Stanford University Press.

Goodman Bryna (1995). Native Place, City, and Nation: Regional Networks and Identities in Shanghai, 1853-1937. Berkeley: California University Press.

\footnotetext{
${ }^{47}$ Kikuchi 1960; Motono 2015.
} 
Kikuchi Takaharu 菊池貴晴 (1960). “Keizai kyôkô to kakumei heno keisha 経済恐慌と革命への傾斜 (The Financial Panic as a Factor of the Chinese Revolution 1911).”東京教育大学アジア史研究会編『中国近代化の社会構造, The Aziashi Kenkyukai of Tokyo University of Education ed. (Social Phase in Chinese Modernization )』汲古書院.

Motono Eiichi 本野英一 (1992). “A Study of the Legal Status of the Compradores during the 1880s with Special Reference to the Three Civil Cases between David Sassoon Sons \& Co. and Their Compradores, 1884-1887.” Acta Asiatica 62, February, pp. 44-70 (later recollected in Chinese Business Enterprise: Critical Perspectives on Business and Management 4 vols., ed. R. Ampalavanar Brown, vol. 2. London and New York: Routledge, 1996, pp. 295-318).

Motono Eiichi 本野英一(1996 [printed 1998]), “H. A. Giles v. Huang Chengyi: Sino-British Conflict over the Mixed Court, 1884-1885.” East Asian History 12, pp. 135-57.

Motono Eiichi 本野英一 (2000). Conflict and Cooperation in Sino-British Business, 1860-1911: The Impact of the Pro-British Commercial Network in Shanghai, Basingstoke, UK: Macmillan/St. Antony's Series.

Motono Eiichi 本野英一 (2012). “Zaika Gaikokujin gawa yori mita 'Danao huishen gongjie an (1905)' ni kansuru ichi kôsatsu 在華外国人側より見た『大閙会審公廨案（1905）』に関する一考察.”In Morrison Pamphlet no Sekai 斯波義信編『モリソンパンフレットの世界』, ed. Shiba Yoshinobu. Tōyō Bunko, March 2012, later recollected with revision in Morrison Pamphlet no Sekai II, later recollected in 2nd edition, eds. Shiba Yoshinobu 斯波義信 and Okamoto Takashi 岡本隆司. Tōyō Bunko, 2017, pp. 327-63.

Motono Eiichi 本野英一 (2015) Shingaikakumei zenya, shanghai shûhen chiiki no tsūka shin'yō seido, 1900-12- sōhyō no dakan kigen mondai wo chūshin ni- 辛亥革命前夜上海周辺地域の通貨信用制度、1900-12、一荘票の召換期限 問題を中心に一」（斯波義信編『モリソン・パンフレットの世界II 近代アジアとモリソンコレクション』， Tōyō Bunko, 2015, later recollected with revision in Morrison Pamphlet no Sekai II, eds. Shiba Yoshinobu 斯波義信 and Okamoto Takashi 岡本隆司 eds. Tōyō Bunko, 2017, pp. 365-405.

Motono Eiichi (2018). "Reorganization of the Mixed Court System in Shanghai, 1906 to 1913," In Asia and the History of the International Economy: Essays in Memory of Peter Mathias, eds. A. J. H. Latham and Heita Kawakatsu. Routledge.

Niida Noboru 仁井田偢 (1960/1981) “Hotei chūgoku hōseihi kenkyū: tochi hō, torihiki hō 補訂中国法制史研究 : 土地法・取引法 (A Study of Chinese Legal History - Law of Land and Law of Transaction).” Tokyo, University of Tokyo Press.

Rowe William T. (1984). Hankow: Commerce and Society in a Chinese City, 1796-1889. Stanford, CA: Stanford University Press.

Yang Mayfair Mei-hui (1994). Gifts, Favors and Banquets: The Art of Social Relationship in China. Ithaca, NY: Cornell University Press.

Cite this article: Motono E (2020). The Import Sales Contract System in Shanghai 1903-1918, with Special Reference to USChinese Commercial Disputes. International Journal of Asian Studies 17, 145-161. https://doi.org/10.1017/ S147959142000025X 